\title{
THE POPOL VUH AND THE BOOK OF CHAN K'IN
}

\author{
By Robert D. Bruce
}

Should the news media predict the end of the world within two or three months, I feel that most of us - I, at least- would laugh, or sigh, and perhaps wonder what kind of mentality it takes to make some poor devil believe he suddenly became clairvoyant or established supernatural contact with the Omniscient, or more likely, the extremes to which some people will go just to see their names in print. Should such a prediction be followed by the name of a renouned astronomer or geophysicist, however, I fear that our indulgent amusement would come to an abrupt end. Whether we would accept the alleged fact or not, we would realize that responsable scholar would not make such a statement without having some very good reasons - right or wrong - for doing so.

I had a similar experience, several months ago, when the news media of Mexico City declared "THE POPOL VUH IS A FRAUD!" I stopped chuckling only when I heard this affimation attributed to Dr René Acuña, of the Centro de Estudios Mayas of the National University of Mexico. I found these same astonishing conclusions in a newspaper report of a conference given by Dr. Acuña, entitled "El Popol Vuh: Poema del mestizaje". I suspected some horrible, sensationalistic distortion (such as newspaper reporters sometimes make) of a more orthodox criticism of the classic work in question on the part of the author, but I found these same disconcerting ideas presented in much greater detail in "Problemas del Popol Vuh", published in Mester at U.C.L.A. from the draft of a conference scheduled to be given at the Centro de Estudios Literarios of the Instituto de Filologia of the National University of Mexico on April 4, 1975. Finally, I established contact with Dr. Acuna, and

${ }^{1}$ In Diorama de Excelsior, the Sunday supplement of the Mexico, D. F., newspaper Excelsior, March 7, 1976.

${ }^{2}$ Mester. Vol. V, Núm. 2, Abril de 1975. University of California, Los Angeles. pp. 123-134. 
we personally discussed his criticisms. He began with undeniably valid stament that "The Popol Vuh has been more 'used' than 'studied", and continued with a series of scholerly and very logical criticisms of the Popol Vuh, elaborated in the same conscientious and meticulous style and methodology as may be appreciated in his "Introducción al Estudio del Rabinal Achi". ${ }^{3}$ These considerations led Dr. Acuña to the conclusion - and, if I may anticipate the points I shall make in the present study, the mistaken conclusion - that "the Popol Vuh is not a native work with biblical and Christian influences; it is a European-Christian work with native influences"."

Probably quite early in grade school, we all began to suspect that History is not "the true and precise account of the sequence of past events", and probably very soon after the first suspicions, we learned the intellectually more convincing definition of History as "a fable agreed upon". Moreover, with a bit of study into any given history, we found that it is not only "a fable", but a fabulous account made up of imprecisions, mistakes, lies, racial and nationalistic pride and prejudice, vested interests of the time, and almost invariably an ethnocentrism which constitutes malicious slandar for almost every group except the historian's own.

Acuña's mistrust and critical analysis of the historic account of Fr. Francisco Ximenez' having found the already 150 -year-old manuscript in Chichicastenango in or about 1701 is far more logically and methodologically sound than the greater part of us simply accepting this "on faith". .. at least provisionally as a beginning point for our studies. We should remember the importance of Epistemology -the proving of the validity of what we accept as "our knowledge"to our traditional logic and scientific methodology. But fortunately for the majority of the students of Maya Cosmology in general and the Popul Vuh in particular, comparative studies continue to provide supportive evidence that the Popol Vuh is made up almost exclusively (if not totally) of pure, uncontaminated Maya (and Mesoamerican) elements, put together according to equally pure indigenous order of sequence and composition. These may be interrelated and recognized in parallel form in other Mesoamerican tradi-

${ }^{3}$ Acuña, René, Introducción al Estudio del Rabinal Achí, Cuaderno 12, Centro de Estudios Mayas, UNAM., México, 1976.

4 El Popol Vuh: Poema del mestizaje (op. cit.) \& Problemas del Popol $V u h$ (op. cit.; p. 130): (1) "El Popol Vuh no es un producto nativo con influencias bíblicas y cristianas: es un producto cristiano-europeo con influencias nativas". (2) "El PV, al contrario, es un producto enteramente cristiano-europeo. Si tiene que hablarse de alguna clase de influencias, habrá que hablar de influencias nativas". 
tions, more clearly and completely with each addition to our knowledge of their basic cosmology. That is to say, the acceptance of the validity and legitimate Indian origin of the Popol Vuh appears to be the right decision, even if this decision was intuitive and in violation of our traditional Epistemology. On the other hand, Dr. Acuña's more correct epistemological approach to the question would appear to have led him to the wrong conclusions.

Perhaps more significant than any methodological consideration, however, is the fact that Dr. Acuna was unfamiliar with the oral traditions of the Northern group Lacandones, which constitute an almost identical version of Parts I and II of the Popol Vuh. In 1971, with the valuable collaboration of Dr. Carlos Robles U. and Ma. Enriqueta Ramos Ch., I published a comparative study ${ }^{5}$ which included a synthesis of these Lacandon traditions (to which I gave the title "The Book of Chan K'in") together with a synthesis of the Popol Vuh, and a camparison of both, contrasted in some points with other selected traditions from parts of the Maya cultural area. Also, in 1974, the original "Libro de Chan K' in" "6 was published in Lacandon original with parallel transliteration and free translation in Spanish by the same Instituto Nacional de Antropología e Historia of Mexico. The failure of any investigator to know of the existence of a study of significance or interest to his investigations, published and collecting dust in one of the warehouses which the I.N.A.H. dedicates to such monographs, should hardly be held against him. To discover such an obscure publication is more a matter of luck than of scholarship.

The authenticity of the Popol Vuh has been challenged, not by a religious fanatic, nor by a sensationalistic iconoclast, but by a welldocumented and conscientious scholar. René Acuña's questions are in the strictest agreement with the traditional logic of scientific methodology in our Occidental schools of the Humanities. The Popol Vuh could well be called the "keystone of the arch" of most studies of Maya Cosmology. If this "keystone" is not the integral part of Maya tradition that it has been considered, but an apocrific fraud perpetrated by the Dominicans in order to christianize the Indians '(as Dr. Acuña concludes), then we must face even more difficult questions: What holds up the rest of the arch (as we conceive of it)? And how did the Lacandones obtain an almost identical version

${ }^{5}$ Bruce, Robles \& Ramos: Los Lacandones: 2. Cosmovisión Maya. Depto. de Investigaciones Antropológicas, I.N.H.A., México, 1971.

'Bruce, Roberto D., El Libro de Chan K’in, Núm. 12 de la Colección Científica (Lingüística), I.N.H.A., México, 1974. 
of it in their oral traditions? And how can all the new data from Archaeology, Ethnology and Folklore interrelate and intermesh so perfectly with it? (Compare this with the "Book of Mormon", which was marvelously sophisticated and in logical agreement with the vague archaeological theories of the time it was written. One by one, the theories in vogue at the time of the fraud were corrected, or modified to the point where they no longer gave their original appearance of support. Anthropology went its own way, leaving the Book of Mormon with only faith to support it.)

Since Dr. Acuña's criticisms are so logical to the Occidental student of the Popol Vuh and related Maya traditions, in order to be consistent with our thinking, we must either answer them logically, or realize that the logic in question in a given case is simply not applicable or valid for the phenomena of Maya culture in question.

I have taken the liberty of presenting in synthesis the principal points of Dr. Acuna's challenge to the authenticity of the Popol Vuh. These arguments are presented systematically in order of:

\section{Narrator}

1. The narrator uses the "omniscient viewpoint", which Dr. Acuña sees as similar to the style of the Bible, but not common to other narratives of the Maya Area. ${ }^{7}$ Old Chan K'in of Naha', however, also uses the omniscient viewpoint in the dictation - or more correctly, in the recitation - of the Lacandones' oral traditions in the "Book of Chan K'in". He often explained to me aside, that these things were so because he had heard them from his father, who had heard them from his father, etc., from the original authority of Nuxi' $\mathbf{A} h$ Lehihbah, "The Ancient Mole Trapper" (actually, a humanized and heroic version of the same solar deity who is Hunahpú in the Popol Vuh), who had gone to the Underworld, seen the things in question with his own eyes, and had been instructed by the Lord of the Underworld, Sukunkyum, to "Go and tell your fellow men what you have seen."

2. The narrator never identifies himself as Quiché, and even less as a member of the native royalty. ${ }^{8}$

7Problemas del Popol Vuh, p. 123: "Además, es omnisciente y obicuo: está en todos los sitios donde se desarrolla la acción, conoce los pensamientos de los actores, y oye lo que conversan".

${ }^{8}$ Problemas del Popol Vuh, p. 124: “...si se eceptúan uno que otro hgar dudoso, el narrador jamás se identifica a sí mismo como quiché y, menos aún, como miembro o descendiente de la realeza nativa". 
It is true that the Popol Vuh does not have a specific declaration of its author and on whose authority it should be accepted, such as in the Título de los Señores de Totonicapan "Here what I am going to relate, what I am going to declare, I, Diego Reynoso Popol Vinak, son of Lahuh Noh..." ${ }^{9}$ On the other hand, a narrative beginning with the original and basic premises of cosmic reality could hardly be attributable to a mortal authority, and in fact, it would be quite presumptious for anyone to take credit for the "Eternal Truths" that he had received as the anonymous tradition of his people. Neither does Chan K'in of Naha' cite himself as an anthority for the traditions he dictated; but only indirectly identifies himself with the material in one of the stories included in Appendix 1 of " $E l$ Libro de Chan K'in" - and I should point out in passing that $I$ gave this title to the narrative, which Chan K'in dictated to me with no title- when he cites his paternal grandfather as one of the actors in an encounter between the Lacandones of the Ma'ax Onen and the last of the Lo'k'in.

Even the most superficial analysis, however, revels that the author does positively (if indirectly) identify himself as Quiché. Consider the implications of the passage in Part III, Chapt. 5, when all the fires, except those of the Quiché who had accepted Tohil as their principal Lord, were extinguished. "'The speech of Balam Quitzé, Balam Acab, Mahucutah, and Iqui Balam is different! Oh! We have given up our speech! What have we done? We are lost. How were we deceived? We had only one speech when we arrived there at Tulán; we were created and educated in the same way. It is not good what we have done,' said all the tribes under the trees, under the vines..." (All, that is, except the Quiché.) Every linguist who has worked with any dialect in the Maya area (or practically any other area) is familiar with his informants' reaction to any other recognizeably close dialect. The inevitable comment is (a cognate form of the Lacandon) $T u k^{\prime} a x a h u$ t'an, "They have changed their speech." The speaker of each dialect assumes quite naturally that his speech, in its contemporary form, was that of the Gods. While this, of course, tells us nothing about which given dialect may be the more conservative, it does positively identify the dialectical filiation of the informant, and in this case, the author of the Popol Vuh identifies himself as Quiché.

- Título de los Señores de Totonicapan. Trad. Dionisio José Chonay, Introd. Adrián Recinos, Fondo de Cultura Económica, México, 1950. 


\section{Language and style}

1. "But the fact is that 'Quiché', in such an abstract sense, doesn't exist. There are several dialects, and no one of them is adequate to understand and to read the Popol Vuh. It would be like trying to use French as a basis to read Vergil." 10

No linguist could deny that there is much truth in this affirmation; in view of the fact that approximately five centuries $-\mathrm{a}$ half a millenium - have passed since it was presumeably written. By comparison once again with the "Book of Chan K'in", I should like to point out that there is a noticeable difference between the recited forms which constitute the Lacandon narrative and the colloquial speech of the same Chan K'in de Naha' in his every day conversations. This difference could almost be compared with that between a middle western American's citing scripture (from the King James version of the Holy Bible) and the same person chatting with his neighbors. It would be interesting to do a conscienteous glottochronolgy of the Quiché of the Popol Vuh and existing Quiché dialects, and if the results indicated more than 5 to 8 centuries minimum separation, then studies should be undertaken to explain the dialectical variation, or the validity of the system of phonemic writing employed in the text. And finally, in terms of Dr. Acuña's own analogy, if French in itself would be inadequate as a basis for reading and understanding Vergil, a linguist knowing French, Spanish, Italian and Rumanian, could probably do rather well without knowing Latin... and please note that the works of Vergil are at least twice as old as the Popol Vuh.

2. Dr. Acuña notes that "Two of the most distinguished translators of the Popol Vuh have observed that it "makes excesive use of passive constructions', that some passage 'have a certain flavor of the Latin absolute ablative', and that one of these [translators] recognizes that he has found of great utility in translating [the Popol Vuh] 'the grammars and vocabularies ... compiled by the Spanish missionaries." " 11

10 Problemas del Popol Vuh, p. 125: "Pero el caso es que 'el quiché', así en abstracto, no existe. Existen varios dialectos. Ninguno, absolutamente ninguno, sirve para entender y leer el PV. Sería como querer usar el francés para leer a Virgilio".

11 Problemas del Popol Vuh, p. 125: "Dos de los más distinguidos traductores del PV han observado que su sintaxis usa 'en exceso de las construcciones pasivas' y que sus locuciones 'tienen cierto sabor al ablativo absoluto latino'. Uno de ellos reconoce haber encontrado de mucha utilidad para traducirlo "las gramáticas y vocabularios... compuestos por los misioneros españoles"." 
While these observations could be of great utility to a more profound linguistic analysis of Quiché, I feel they hardly constitute proof that the author of the Popol Vuh was an Occidental, accustomed to writing in Latin.

As I will demonstrate a bit farther on in this study, the distinction between "verbs" and "nouns" is not appropriate for the grammatical analysis of Lacandon, nor of other closely related Peninsular Maya dialects. Those Occidental scholars who project these grammatical classifications to the analysis of Peninsular Maya grammatical structures usually have a hard time explaining the "excessive irregularities" (without committing the absurdity of blaming it on a "primitive mentality") and often depart a great deal from the meaning in the Maya original. Considering the relative closeness of the two Mayanse dialects, Lacandon and Quiché, and the distance of both from the Occidental languages, I suspect that the gramatical classification of "verb" may be as unappropriate for the analysis of Quiché as it is for the analysis of Lacandon; and if verbs don't really exist in Quiché, then a new grammatical analysis is certainly neces. sary before we speak of the "passive voice" and the "absolute ablative" in this language. However, in speaking of the danger to valid linguistic anaylisis of projecting Occidental grammatical classifications and analyses to Mayan Languages, where, are not valid, I should not care to fall into the error of possibly projecting classifications and analyses valid for Lacandon to Quiché texts, for which they might not be appropiate. I prefer to leave these considerations for the specialist in Quiché and related Highland Maya dialects.

As for the mention of the language of the Popol Vuh being far more similar to the "grammars and vocabularies compiled by the Spanish missionaries" than to any contemporary dialect of Quiché, it could hardly be otherwise. For one thing, these were centuries closer to the original; and for another, the "original" being copied by Fr. Francisco Ximénez, it seems quite logical that he would "correct the spelling" to the dialectical forms familiar to him, whether he tampered with the content (as Acuña believes) or whether he respected it (as I believe he must). This resemblance leaves us with the same logical possibilities, and proves nothing.

\section{Content and aims of the work}

On the basis of numerous examples, Dr. Acuña concludes that the theme of the Popol Vuh being that man was created for the 
sole purpose of adoring and glorifying the name(s) of his $\operatorname{God}(\mathrm{s})$, the first ancestors having worshiped the true God of Heaven until they were deceived and given idols by a bat-winged demon from Xibalba... this was all a fraud set up by the Christian missionaries in order to convince the Indians to "return to the true Faith of their Fathers". i.e., Christianity.

In the first place, the "religious devotion", or that cultural characteristic which might be called "theocentrism", would appear to always have been far more pronounced among the Mayas than in any Occidental culture that I can think of offhand; from the man-hours per capita which must have been dedicated to the construction of the classic ceremonial centers, to the great percentage of the present day Lacandon man's time and effort which is dedicated to ceremonial duties. The degree of religious devotion of practically any traditional Maya would rival very well that of the most fanatical of professional Christians (i.e., missionaries). The primary importance of religious duty before all else is in perfect agreement with Maya character.

This brings us to the very interesting and puzzling reference to the "messenger of Xibalba" in Part III, Chapter 5. I think all of us have simply accepted this as a "Christian influence" in the original Quiché narrative, and at best, wondered just how profound and significant it might be in terms cosmology. After the rain had extinguished the fires of all the tribes, Tohil appeared to Balam Quitzé and Balam Acab, and gave them fire. After the rain falls a second time, extinguishing all the fires except those of the Quiché, the others come to them begging for "a little of their fire". It is at this point that the "man of Xibalba" appears (literally "like a bat out of Hell"), telling the Quiché not to give away the fire except against the promise of (almost) all the tribes to "give up their waists and their armpits", that is, to provide the Quiché with sacrificial victims. In summary: This "man of Xibalba" gave them the cult to the image (or "idol") of Tohil, he had wings like those of a bat, he claimed to be a messenger of the Creator though he crearly came from Xibalba, the Underworld, and he gave indications for human sacrifice.

This had always seemed to me (as apparently it had to most other investigators) to be the very clear implication -if not clear statement - that the Quiché were deceived by and underworld deity into accepting "idolatry" in place of the original cult to the solar deities, and together with it, human sacrifice and giving Tohil, the god of 
war, ${ }^{12}$ an importance out of proportion to his rank and position in the pantheon of gods. It did not even occur to me to doubt it until after long and detailed consideration of the corresponding passage in the Book of Chan K'in (Chapt. XXIII). This may be summarized as follows:

After the Flood, the present era of Mankind began. Äkinchob (or Xh K' in Chob) protected all living things, "The Procreators", until they had propagated enough to resume life according to the natural order without the direct intervention of the gods. He presents the Lacandones' ancestors with the sacred incense burners which bear the effigies and names of the gods; though two previously unmentioned deities are included among the incense burners, and are thereafter given an importance which is hard to explain. These are Itsanal and Säkapuk, who would appear to be Hunahpu and Tohil, respectively, but on the purely ceremonial level.

Itsanal -a clear cognate with Yucatan Itzamná, the principal solar deity - has only this important name; but he has no importance in the cosmology. Säkapuk (or $S a ̈ k-K a b-P u k$ ) can be translated literally, "Venus-Destroyer", or "the Morning Star as God of War"; but in name only. It would appear that Säkapuk corresponds to the image of Tohil, though on the near cosmic level, it is the Lacandon $A^{\prime \prime} h K^{\prime} a k^{\prime}$ who corresponds on the one hand to Tohil and on the other to Xbalanqué.

Akinchob tells the people that they can no longer see nor speak directly with their gods, and that they must now pray to them through their incense burners. He tells them that man's participation in the supernatural is reduced to the ritual in the statement "You see, but you don't see. What to your sight is incense, is not incense."

I am afraid that the description of the "man of Xibalba" too clearly evoked our memory of Doré's gravings of Lucifer and the fallen angels in Milton's "Paradise Lost", and we have unconsciously

12 Tohil is often considered to be a rain god, as toh (especially in written forms) is said to refer to "rain" in several of the highland mayanse dialects. I feel rather certain, however, that the form written Tohil should be a cognate form of the Peninsular Maya T'o'oh-il, "Great One" or "Venerable One" (deriving from t'o'oh, "great, venerable") The adaptations of the Spanish alphabet which were taught to the Indians did not provide (usually) for the writing of glottals nor of glottalized forms, so the native authors - who would never confuse glottalized and simple consonants in speech- usually did not differentiate them in writing, leaving them to be reconstructed on the basis of context. In any event, there are far too many features identifying Tohil with the Lacandon $\ddot{A} h$ K'al'. These characteristics. the multiplicity of personalities and aspects, is treated in detail in Bruce, Robles \& Ramos (op. cit.) pp. 95-104. 
translated Xibalba as "Hell", with all (or at least, too many) of its Occidental connotations. But can we really be so certain that this was what the Quiché author had in mind? Let us consider the implications of this "man", who was more correctly an underworld deity, who came to instruct the Quiché to initiate human sacrifices in the Mesoamerican tradition. In other words, at this point in the narrative, the Quiché were on the threshold of initiating the ritual and ceremonial drawing of blood for the glorification of the gods. Maya cosmology conceives of the natural and the supernatural as forming a single, harmonious whole, and within this natural order, it would be difficult to find a more appropriate animal prototype to symbolize the drawing of blood than the vampire. It is thus quite possible that the "bat's wings" of the "man of Xibalba" might have no association at all with the European's "demons of Hell", unless one would care to reach all the way down to the level of universal nocturnal symbolism... and it is necessary to remember that the factors of connotation are independent of basic meaning and origin, though they may sometimes take on even greater importance.

Then regarding the Maya meaning of the Underworld (the Quiché Xibalba and Lacandon Yalamluum) we should remember that this is not the equivalent of the Occidental's Hell. It is more like Hades, or a single region including both Elysium and Tartarus. We should also remember that this occurs at a point in the sequence of the narration after Hunahpu and Xbalanque had overcome the people of Xibalba (Part II, Chapt. 13-14), sacrificing most of the Lords, sparing only those who humbled themselves, accepting their "lowered rank" under the dominion of the solar deities. This is paralleled in the Book of Chan K'in (Chapt. XVIII) when T'uup repeatedly kills and decapitates Kisin, the Lord of Death. Each time, however, Hachäkyum brings Kisin back to life, informing T'uup that Kisin belongs in the natural order of reality. Kisin remains under the supervision of the stern, just and benevolent Sukunkyum, the "Dead Sun", or Solar Lord of the Underworld. Kisin symbolizes Death subjected to the order of Life, presided over by the solar deities; and this appears to be, with minor individual variations, the basic cosmological concept shared by the Peninsular Mayas, the Highland Mayas (including the Quiché), and probably by all Mesoamerican cultures. ${ }^{13}$

${ }^{13}$ Cf. Porro, Antonio: Quetzalcóatl e Hun Hunahpú: Mitos homólogos nauha e quiché, Revista de Antropología, Vol. XVII-XX ( $2^{*}$ parte), Caixa Postal 5459 - Sao Paulo, 1969-72. pp. 323-338. Dr. Porro's article represents an excellent start at determining the prototype deities for Mesoamerica. 
In view of the fact that Xibalba is not Hell, where Lucifer and the fallen angels sit plotting against God and His creatures, there is no reason that the "man of Xibalba" could not be exactly what he said he was: "...a messenger of your Creator, your Maker", and in honest agreement with the harmonious whole of natural and with supernatural reality. His vampire characteristics and associations with the Realm of Death (Xibalba) could be interpreted simply as appropriate emblems of his commission, to establish the custom of ceremonial blood drawing from sacrificial victims, and their death according to an order dictated by the Solar Lords of Life.

The foregoing is perhaps the best possible example of the manner in which what would first appear to be the most blatant acculturations, upon detailed analysis, can be explained in terms of pure Maya symbolism.

Regarding the use (or mis-use) of apparently calendrical names in the Popol Vuh (i.e., Hun Hunahpú and Vucub Hunahpú, Hun Camé and Vucub Camé, Vucub Caquix, Hun Ahau... and probably Huracán should be interpreted Hun-Racan, in literal opposition to the Earth-giant Cab-Racan; and Hunahpú is quite clearly $H u n-A h-P u$ ), we must face the fact that it would be rather presumptious of anyone to claim that he really understands the Mesoamerican Calendar, or has anything approaching an exhaustive knowledge of its symbolism and implications. The fact that we recognize the progression and order of the days, the 13, 20 and 260 day periods, and their sequence in relation to the solar year in the great 52 year cycles, etc., etc., and our ability to recognize, by means of the mathematics involved, that the Mayas (Otomíes, et al.) were registering what we also measure in solar, lunar and Venus cycles... is not at all the same thing as really understanding what the Mayas had in mind when they dealt with these phenomena.

We know that historic Mesoamericans carried the name and numeral of their birthday as a proper name, but this could hardly be the case of the gods. The logical argument that the birthday of a real, mortal god impersonator came to be projected to the original god he represented somehow fails to convince me. God images are born in the human mind, and whenever a specific day was designated to a god, the reasons were invariably of the order of cosmic symbolism. In our own Occidental culture, for example, no one knows for certain when Jesus of Nasareth was born. Our students of biblical history admit that they simply have no clear, authoritative evidence; and our astrologers are almost all in agreement that it could not 
have been December 25th; as the character of the historic person could well have been Arian, but hardly Capricornian! We do know, however, that the salvation cult which was one of the most powerful rivals which early Christianity had to swallow and incorporate was Mithraism. Mithra ${ }^{14}$ was a solar deity, and the winter solstice was holy to him. (The old world astrologers clearly demostrated their inferiority to their Mesoamerican colleagues by miscalculating the winter solsctice as the 25 th of December.) Christianity simply appropriated the holiday, making the conversion easier and less traumatic.

Without presuming to understand the profound symbolism involved, I should like to point out that the form Hun. "One", in the names of the deities of the Popol Vuh invariably refers to Solar Deities, and Vucub, "Seven", invariably indicates a god who may be associated in one form or another with the Morning Star. It is surely significant that the seventh day of the calendar is that corresponding to "Deer", an emblem of Tohil, Äh K'ak', Quetzalcoatl, $X$-balam-QUE...

Finally, the overall parallel -in form and sequence as well as in content- between the Highland Quiché's Popol Vuh and the Peninsular Maya Lacandon's Book of Chan K'in is the best possible proof of the authenticity and pure Maya origin of both. I should point out that the Northern Lacandon narrative was recorded in conditions which permit no doubt as to its pure Maya origin. The Lacandones were never subjected politically nor socially to Cristian missionaries during the Conquest nor the Colonial period, and there was simply no way that they could have obtained an adulterated version of Maya cosmology, even if they had wanted to. In view of the striking similarity between the Lacandon and Quiché narratives, it is logically obvious that both must be authentic, pure Maya. For one to be a fraud, it would not only be necessary for the other to be fraudulent also, but it would be necessary for both to be the SAME fraud.

${ }^{14}$ Cf. Herbert J. Muller's "The Uses of the Past", Oxford University Press, 1952. "Mithraism in particular was similar to early Christianity in many ways. Its followers formed secret societies and called themselves Brothers; they admitted the lowly, even to slaves; they performed the rites of baptism and communion; they celebrated their sabbath on Sunday, and an annual festival on 25 December; they had a categorical ethics, stressing continence and abstinence; their dead were resurrected, to go to a heaven above or a hell in the bowels of the earth; their god Mithra had made a sacrifice which saved the human race; and he was a mediator between the supreme God and man. Greek philosophers emphasized all these parallels-to the advantage of Mithraism. Modern scholars are not certain to what extent the two religions borrowed from one another, but it seems probable that their similarities owe largely to their common debt to older religions, especially in Persia". 
Having mentioned the Northern group Lacandones and the Book of Chan K'in, a product of their culture, as arguments to answer the challenge to the authenticity of the Popol Vuh, our traditional logic demands definition of terms and characterization of the material referred to.

\section{LOS LACANDONES}

In speaking of the Lacandones, I should clarify brielfly the meaning and origin of the name, and consequently make as clear as possible the number of ethnic groups or sub-groups of Peninsular Mayas to which it now refers, or may have referred to in the past. The original Peninsular Maya term appears to have been Ah Akan-tun, and can be analyzed $A h$, "he" or "they" + akan, "set up, standing" + tun, "stone, precious stone, stone idol". Landa ${ }^{15}$ mentions the Ah Acantun as functionaries in the traditional Maya rituals. The Ah Akantun (-oob) were literally "(those who) set up (and worship) stone idols". They were "the stone-worshippers, the idolaters, the pagans", and apparently this term was used by christianized Mayas to speak (disdainfully) of their unchristianized, traditional neighbors. The name was used in Spanish in the geographic sense, and " $E l$ Acantún" referred to the unexplored Usumacinta Basin, where the population was so scarce and so poor, and the jungle so unhealthful and uninviting that military expeditions were simply not worth the effort. ${ }^{16}$ "El Acantún", became "El Lacantún" and the inhabitants were called "los lacantunes" and eventually "los lacandones". It is at present most difficult to say just how many small ethnic groups inhabiting this vast region were at one time or another classified as "Lacandones" - in the literal sense of "idolatrous Indians"though it is possible that there were as many independent groups as there are ruins of ceremonial centers in the area. Probably each group maintained a good degree of isolation dating back to classic times. What all groups had in common, however, was that they were all Peninsular Mayas with the same cultural origin and heritage. (The mention of "Chol speaking Lacandones" implies the possibi-

\footnotetext{
${ }^{15}$ Landa, Fr. Diego: Relación de las Cosas de Yucatán, Ediciones Porrúa. México 1959 . pp. 101.

${ }^{16}$ While it is true that many of the religious officers had a genuine interest in saving the souls of the most humble of the poor pagans, the souls of the rich pagans (i.e., those with gold, or more often, with large populations and negotiable products) were usually attended to first.
} 
lity of a greater linguistic variation than the presently-recognized linguistic group composed of Yucatec-Lacandon-Itzá-Mopan, but one could still include Chol and Tabasco Chontal with the previously-mentioned Peninsular Maya dialects and have a single linguistic group of dialects as opposed to those of the Maya Highlands... and the original cultural similarity - before the civil and religious domination of the Colonial Spanish and the Republican Mexicans - was roughly identical with the linguistic differences).

Only two groups of these traditional Peninsular Mayas have survived to very recent times unchristianized and unacculturated. I must mention in passing that in the past decade, the Southern group of Lacandones was converted to christianity by American protestant missionaries, and at present approximately half of the more conservative Northern Lacandones have been converted by these devout followers of Fray Diego de Landa who continue the task of destroying the native cultures and traditions before we can come to understand them, except to recognize aspects of knowledge so refined and intellectually stimulating that the early Spanish religious officers could only attribute them to the inspiration of the Devil. As students of Anthropology, we were all told that we mustn't judge Landa too harshly, without taking into consideration the ignorance, prejudice, superstition and religious fanaticism of his time. Even if Landa's personal beliefs and values had been totally in agreement with present-day standards of the Humanities, he could hardly have acted differently than he did without ending up in the hands of the Holy Inquisition. But even if Landa's intolerance and destruction should be tolerated because they occurred at the beginning of the Sixteenth Century, I have yet to discover what might justify his emulators in the last quarter of the Twentieth Century.

The present day Lacandones of Najá and (half of those) of Lake Mensäbäk, are the last Peninsular Mayas to conserve intact (except for sligth internal modification, evolution and abreviation) their local version of a single religion common to the entire Peninsular Maya area. All data from these Lacandones' traditions tend to associate the Northern group with Palenque, and the Southern group with Yaxchilán, and until I am given reasons more convincing than the inferences of my own investigations (from 1953 to present) to believe otherwise, I shall continue to consider them the direct descendants of the theocratic nobilities of the mentioned ceremonial sites.

The early Catholic campaigns for the Christianization of Indian ethnic groups -in this case, the mayance groups - seemed content 
to achieve the acceptance of the Catholic ritual, and the Indians were allowed to conserve their traditional beliefs and cosmology almost totally intact, as long as the original deities were called by the name of Catholic Saints... even if Jesucristo was frequently associated with one of the fearsome underworld Lords of Death (and his cult was propiciatory) and Santo Tomás was the Spanish name given to the young solar deity who is called Hanahpu in the Popol Vuh and Nuxi' or Nuxi' K'ak' in the Book of Chan K'in. Among many of these nominally Catholic Highland Maya groups, it is still possible to conduct studies of the original Maya cosmology - provided the Christian influences are recognized, sorted out and evaluated. The oral traditions of the Northern Lacandones, however, which I recorded and published in Spanish in 1974 as "El Libro de Chan K'in" through the Instituto Nacional de Antropología e Historia of Mexico, is possibly the last chance we will ever have to record the pure, original Maya traditions without the need for evaluation of foreign influences, and the reconstruction of the original.

There still remains the possibility of obtaining the Southern Lacandon equivalent, as the Belgian ethnologist Didier Boremanse has found a young Southern Lacandon who is willing to recite some of the old narratives. The father of the young informant, however, who would be the most appropriate person to dictate the Southern version, is now a faithful protestant Christian who is reluctant to sing the old songs, and refers to them as Kisin u k'ay, "the Devil's songs."

\section{COMPARISON OF THE LACANDON AND QUICHE NARRATIVES}

Whether or not it be "Universal logic", the Occidental thought and logical procedures which we share (you and I, reader and writer) dictate that "Entities are, if not virtually meaningless, at least logically unmanageable, unless they can be compared and contrasted with something." The existence of a parallel version of the Popol Vuh in the Lacandon Book of Chan K'in offers us the greatest possibility so far of understanding the one by comparison with the others: Many points which to present have had to remain as simple hypotheses may now be definitely confirmed or rejected by this comparison. Moreover, the striking similarity between the two narratives confirms a far greater uniformity in basic Maya cosmology than I personally would have anticipated between the Highland and Low- 
land (or Peninsular) Mayas. We should remember that the linguistic and cultural differences between the Lacandones and the Quiché were far greater than between the Lacandones (or any other Peninsular Maya ethnic group) and the Tzeltal-Tzotzil or Tojolabal groups. When both narratives are compared with the wealth of legends recorded in Thompson's "Maya History and Religion", we become aware that it is just about as valid to of a single tradition which might be called "Maya Cosmology" or "Maya Religion" as it is to speak of "Christian Religion". It is obvious that logically and philosophicly, the differences between Catholic, protestant and Orthodox Christianity are insignificant... regardless of the frequency with which the fanatics of one division have used their minor differences as a pretext to declare war on the members of another division. Every investigator has been told in each and every valley of the Maya area that "All the people in this valley are good and hospitable people, but God help you if you go over the hill! There they are all liars, thieves and murderers". We are thus aware of the fact that the Mayas have always been about as stupid and intolerant regarding the minor differences between independent ethnic groups as we Occidentals have been in the course of our bloody and warring history. About all that can be said to the credit of the Mayas in this respect is that their cosmology makes them less aggressive and efficient warriors than we Occidentals have always been, and will probably continue to be for quite a few years more.

Many of the themes which appear to remain obscure and doubtful in the poetry of the Popol Vuh may be recognized in simple and clear language in the Book of Chan K'in, clearly confirming one of several possible means of interpreting the story. And conversely, many of the clearly expressed stories of the Popol Vuh (for example, the successive creations and destructions of races of Mankind) are implicit but under developed - though clearly identifiable- in the Lacandon narrative. Moreover, certain passages prove clearly in their comparison that what is expressed as a single story in the Popol Vuh is frequently an allusion, on two or more simultaneous levels of meaning, to other associable but distinct lines of narration.

This Classic Maya literary style (known in Yucatán, as "The Language of Zuyua") appears to be far less developed in the Popol Vuh (written in a newly-acquired phonemic alphabet which was in itself probably quite a load on the Quiché author) than in, for

17 Thompson, J. Eric S.: Maya History and Religion, The University of Oklahoma Press, Norman, 1970. 
example, the Books of Chilam Balam; and these in turn were probably far less complex and esoteric than the hieroglyphic writing on the monuments and in the codices. The Lacandon narrative is even simpler in this respect than the Popol Vuh, as it enters into simultaneous multiple levels of meaning only in the fixed ceremonial titles, and in a few passages of the older ceremonial chants. In any case, among the present day Lacandones, the remnants of this classic literary style may be said to be represented only by isolated linguistic fossils.

If we ever come to understand and dominate this literary style -as I believe we must if we are to ever really understand what was written in Maya hieroglyphs - it will probably be only through our established logical tradition of progression from the simple to the complex: from the Book of Chan K'in, through the Popol Vuh, through the Books of Chilam Balam, to the Classic Maya texts of the codices.

Titles of the Gods.

One of the most valuable contributions of the Book of Chan K'in toward the better understanding of the Popol Vuh is the help that it offers in the identification of the deities of the Popol Vuh, who are more often than not mentioned with a recitation of numerous titles... with the titles far outnumbering the mythological persons in question. In the Lacandon narrative, the gods are usually identified by means of a single title, or at most, two or three variants which were clearly identified by the informant as such. In identical portions of the two narratives, by identifying the deity in question in the Lacandon version, it is frequently possible to recognize a great number of titles corresponding to a single deity of the Popol Vuh, or at least to a single position in the pantheon. For example, on the position and in the function of the Remote God, the Lacandon $K a^{\prime} k^{\prime}$ och or K'akoch (the two similar forms are used in free varia. tion with reference to a single deity), we find the titles in the Popol Vuh: Xpiyacoc (of uncertain meaning and derivation), HunahpuVuch (Universal-God Opossum), Ca-mul Qaholom (Two-times Father: Grandfather), Nim-Ac (Great Boar), Zaqui-Nim-Ac (Great White Boar). All of these titles almost certainly correspond to a single mythological person, the Remote God.

The wife of this Remote God - whose name and function have been lost among the Lacandones- may be recognized in the Popol 
Vuh, and by analogy be identified with all of the following titles: Xmucané or Chirican Xmucané, Hunahpú-Utiú (Universal God(dess) Coyote), Ca-mul Alom (Two-times Mother: Grandmother), Nima-Tziís (Great-Coati), Zaqui-Nima-Tziís (Great-White-Coati).

Moreover, these deities, the original or Remote Creator Couple, may be called by the general titles: Tzacol/Ah Tzac (Creator), Bitol/Ah Bit (Maker), Alom (Bearer-of-sons: Mother), Qahalom (Begetter-of-sons: Father). These titles may be used to refer not only to the Remote Creator Couple, but to other important gods as well; though most frequently to the closer Creator Couple, known to the Lacandones as Hachäkyum (Truly-Our-Lord) and $X k^{\prime} a(n)$ $l e$ 'ox (She-of-the-Sacred-Breadnut-Leaves). In the Popol Vuh, importance is given only to the God Huracán (corresponding to $\mathrm{Ha}$ chäkyum) while his wife, the Quiché equivalent of the important Lacandon goddess $X k^{\prime} a(n) l e^{\prime} o x$ or Äkna'i(l) Hachäkym (Our Lady (the wife) of Hachäkyum), appears to be mentioned only brielfly and in passing with the name or title of Xcanil (probably $X$-ka'an$i l$, "She-of-Heaven") and/or Xganel (X-k'an-il, an even closer cognate with $X k^{\prime} a n l e$ 'ox). This "slighting" the principal solar goddess may be one of the few Christian influences in the Popol Vuh, as the author on occasion clearly calls Huracán "Dios" (God), even though "Dios" is also used to refer to "The God of the Invaders" ( Quezalcoatl prototype, in all probability). We cannot be certain that the prospective "spiritual guide" of the Quiché author, who taught him to write with the Spanish alphabet, way not have been very vehement in his contention that "God has no Wife!" On the other hand, this could very well be a Quiché variation of the original Maya theology. Since the Quiché were possibly the nearest thing to true warriors that Maya Culture in general was able to produce, the warriors' logical "male chauvinism" may have begun to give lesser and lesser importance to the original Principal Goddess, just as the ancient Hebrews began to discriminate against Asheroh, the original Wife of Yahweh or Jehova. When The Lord became "a Man of War", He left His Consort - together with Her silver groves and Her silver doves- abandoned in oblivion.

The comparison of the Lacandon and Quiché narratives also allows us to identify what might be called "The Maya Trinity" - or possibly more correctly, "The Three Suns (or Eras) of the Mayas":

1. The "Dead Sun" is the Lacandon Sukunkyum, "Elder Brother of Our Lord", and the Quiché Tepeu, "Prince, Conqueror". 
2. The "Second Sun" or "Previous Era" is the Lacandon Äkyantho' (the God of Commerce and Foreigners) and the Quiché Cucumatz, "Feathered Serpent", clearly identifiable with Kukulcán, or Quetzalcoatl, associable with the god of the Toltecs, in whom the Mayas could well have seen the prototype of the invader and conqueror. Several Northern Lacandones have even assumed that Jesucristo must be the son of this deity, whom they see principally as the God of Commerce. (Here, however, there is an unfortunate confusion, or dualism we don't yet understand, between solar and Venus associations. This will be dealt with -in as much as it is possible to deal with it - farther along in this monograph.)

3. The "Present Sun" (or "Era"), the Creator and Lord of the present world and race of men, is the Lacandon Hachäyum (Hach Äk Yum), "Truly Our Lord" or Yumbili Ka'an (Yumbil-il or Yum Bilim Ka'an), "Lord of Heaven" or "Lord Heart of Heaven". This same deity is known in the Popol Vuh by the titles Huracán and U Qux Cah, "The Heart of Heaven".

Regarding the identification of this third and most important deity, it is necessary to take into consideration one of the significant differences between the basic cosmology of the Popol Vuh (as a representative of the Highland Maya cultures) and the Book of Chan K'in (representing the Peninsular Maya area). Huracán is the (Present) Sun, and he is almost totally in charge of executing and maintaining order in the present world inhabited by the present creation of Men. (Even though other more remote - and possibly more powerful- cosmic forces, deified as "beings", are recognized, $\mathrm{He}$ is from the human point of view, the most important, Supreme God.) Huracán's primary functions are the manifestations of the Sun and the Rain. He occupies that section of the pantheon which in the Peninsular area corresponds to two distinct and very important gods: The Lacandon Hachäkyum and Men-säbäk, the "PowderMaker" or Lord of the Rain. In Yucatán, these two deities were Itzamná and Yum Chaac, respectively. The Tzeltales, the closest Highland neighbors of the Lacandones, also recognize a single principal god (usually called Santo Tomás) who is usually worshipped in his function as Lord of Rain. ("Dios Padre" or "God the Father" refers to the Remote God.)

This cosmological difference would appear to correspond directly to an ancient ethnic division into what are now known as Highland 
and Peninsular Maya groups, and the geographic boundry would also appear to correspond roughly to the present boundry between the Northern Lacandon and the Tzeltal areas, since archaeology tends to support this with the recognition of both Long Count and Calendar Round dates on monuments on the "Peninsular" or "Lowland" side of this line, and the exclusive use of calendar round dates on the Higland side.

In the Peninsular Area, we know that in Yucatán, the cult to Yum Chaac, the Rain God, rivale that to Itzamná (the Sun), and possibly even surpassed it among the agriculturally oriented peasant population. Among the Lacandones, we find that while Mensäbäk carries out his functions under the orders of Hachäkyum, the Book of Chan K'in (Chapt. VII) tells us how Mensäbäk at one time rebelled against the supremacy of Hachäkyum and had to be conquered by force by Xulaab, "The Morning Star", who acted under the orders of the principal solar deity, Hachäkyum.

The Lacandon Onens, or symbolic animals identify Hachäkyum (who is Itzamná in Yucatán and Huracán in the Popol Vuh) as a solar deity of the Monkey Onen and Mensäbäk, the Rain (Yum Chaac in Yucatan, and simply a function of Huracán in the Popol Vuh) as an earth deity, of the Boar Onen. The heirarchy of the Rain God's assistants is but a modified reflection, of slightly lower rank or importance, of that of the Principal Solar Deity. Of great interest is the assistant to each who is called $A h K^{\prime} a k$ ', "Fire Lord" among the Lacandones, and who had the name or title of Nacon or Nacom in Yucatan. (Fray Antonio de Margil ${ }^{18}$ also register Macom as El Rayo or "The Lightning" among the supposedly "Chol Lacandones" of Dolores, undoubtedly referring to the same deity.) Both the Lacandon "Fire Lords" ( $\ddot{A} h K^{\prime} a k$ ') are of the Deer Onen, clearly associating them with Tohil and Quetzalcoatl; and they are personifications of the Morning Star, Xbalanqué, though clearly associable with Kukulcán (Gucumatz) and Quetzalcoatl. The Lacandón Äh K'ak' ti' Hachäkyum (or Hachäkyum's Fire Lord) is the important god of Hunting, Courage and Arrow-making, while $\ddot{A} /$ $K^{\prime} a k^{\prime}$ ( $\left.t i^{\prime}\right)$ Mensäbäk is the rather unimportant and poorly characterized assistant of $M e n s a ̈ b a ̈ k$, apparently very similar to $\ddot{A} h K^{\prime} a k^{\prime} t i^{\prime}$ Hachäkyum in everything but status and importance. He is mentioned only in passing and only in one portion of the Lacandon narrative, together with the numerous other assistants of the Rain God, and

${ }^{18}$ Marimon y Tudo, S.: Fray Antonio Margil über die Lacandonen. Zeitsehrift für Ethnologie, T. XIV, pp. 130-132. Stuttgart, 1965. 
when Hachäkyum sent the Morning Star (called Xulaab, though upon analysis, this would be his "Fire Lord", $\ddot{A} h K^{\prime} a k$ ') to crush the Rain God's rebellion against his authority, this one being defeated all of them.

In Yucatán, Landa ${ }^{19}$ describes the two functionaries of the theocratic society called Nacon or Nacom. The "Nacon ti' Itzmná" was the much respected (or worshipped) war chief, or a species of military dictator in time of war. The other, the "Nacon ti' Yum Chaac" was the functionary who sacrified the victims dedicated to the Rain God, and according to Landa, the attitude of the people toward this person was highly questionable, with regard to "respect".

In the Madrid or Tro-Cortesian Codex ${ }^{20}$ the title ${ }^{\prime \prime} h K^{\prime} a k^{\prime} K^{\prime} a n$, "Celestial Fire Lord", identifies a god associated with the Principal Solar Deity (p. 38) and then again, on p. 11, there appears a figure of apparently lesser importance (among the assistants of the Rain God on pp. 10-11) who appears to be identified as $A h K^{\prime} a k^{\prime} M o^{\prime}$ Yum Chaak Ah-Sak-Kab, "Lord Fire Macaw (of) Lord Rain, Ah Sak-Kab (a title of Venus)". This apparently would confirm the postulated theological division between Highlands and Lowlands or Peninsular Area by means of the deification of the Sun and the Rain as two independent persons in the latter, and as one in the former... in accordance with the general agreement that the Madrid Codex corresponds to the Peninsular Area.

One of the most unfortunate confusions regarding the identification of deities in the Popol Vuh which it has been possible to correct by comparison with the corresponding portions of the Book of Chan $\mathrm{K}$ 'in is that portion of Part II, Chapt. 14 (Referring to the resurrection of Hun-Hunahpu and Vucub-Hunahpi by "their children", Hunahpu and Xbalanqué): "One was given the sun, the other, the moon. Then the arch of heaven and the face of the earth were lighted. And they dwelt in heaven."

This implication - apparently the clear statement - that the "hero twins" of the Popol Vuh were "the Sun and the Moon", is possibly the most discordant and antilogical note in the Quiché narrative. Throughout the whole Maya Area and Mesoamérica -and, in fact, most of the world - the Moon, as a deity, is distinctly and invariably feminine. On the one hand, it is conceivable that this might be the result of the meddling of some Spanish Christian reli-

19 (Op. cit.) p. 51.

${ }^{20} \mathrm{My}$ interpretation of several hieroglphic passages from the Tro-Cortesian (or Madrid) Codex is in preparation, and hopefully, will soon be ready for publication. 
gions officers who simply never understood the profund symbolism and significance of the narrative; but on the other hand, it is more likely another of those profound multiple-level allusions. which we simply do not yet understand. If we consider Hunahpú and Xbalan$q u e ́$ (who are in effect, the same mythological beings as "their fathers", Hun-Hunahpú and Vucub-Hunahpú) as "the Sun and the Moon", then nothing would appear to make much sense. From the point of view of the greater part of the corresponding myths from the whole Maya Área, Hunahpú and Xbalanqué are "the Sun and the Morning Star", respectively. The Moon is most clearly characterized in the Popol Vuh (Part II, Chapt. 3-4) as "the Maiden Xquic, daughter of Cuchumaquic". She is clearly identifiable with "the Daughter of Kisin" in the Book of Chan K'in (Chapt. XXV, XXVI, XXVII).

Regarding this "masculine moon" allusion, which adds complexity and even apparent contradiction to the narrative (especially in the unilinear translations which Occidental scholars stubbornly or involuntarily project to the Maya originals), I should like to point out a few details which rather elearly identify the different levels of simultaneous narration; even though to follow the intertwined threads for any distance, sorting them out with the proper distinction and associations, would require much more depth and complexity that I intend in the present study. (Some day we must do this, to obtain greater validity than is possible on the present superficial level of analysis; but neither must we be premature about it.)

Just as there were several creations of men (the first of mud and the second of wood were unacceptable and had to be destroyed) so were the original gods who were to be (or possibly to possess) the sun and the moon unworthy of their inherited position, and had to be replaced by others. In the Maya area, they were replaced by their younger brothers. This basic theme of Mesoamerican cosmology may also be recognized in the variant story recorded in the Informantes de Sahagun: ${ }^{21}$ The noble but pampered prince, Tecuzistecatl had to be replaced at the last moment by Nanahuatzin. In this version, both the sun and the moon (Nanahuatzin and Tecuzistecatl, respectively) are masculine.

In the Popol Vuh, the two unworthy brothers '(i.e., both masculine) were called Hun Batz and Hun Chouen, and were turned into monkeys. The ba'ats", "howler monkey" and chouen appears to be an archaic term for the present Peninsular Maya ma'ax, "spider mon-

21 In "Los dioses se mudan en sol y luna". 
key". (In the Book of Chan K'in, these characters are the Chäk $X i b$, "Red Lords", and the older brothers of T'uup, "The Little One", Owner of the Sun.) Among the Lacandones we find that the spider monkey, a day creature, symbolizes the sun: The male of the species is called K'ulel (äh k'ulel ma'ax, "a male spider monkey"), in which we recognize the name of $K^{\prime}$ ulel, a solar deity; ${ }^{22}$ and the female is called cheh (cheh ma'ax, "female spider monkey"), which would appear to be a variant of $\mathrm{Chel}$, clearly recognized in the name or title Ix Chel, the "Pale Lady", or the Moon. In the gender terms of the nocturnal howler monkey (ba'ats'), we find that the male is called k'ooch (äh k'ooch ba'ats', "a male howler monkey or ape in general"). The term k'ooch suggests the name of the Original or Remote Solar God, $K a^{\prime} k^{\prime} o c h$, but the possibilities of derivation and the implications are too many and too vague to do much with at the moment. The female is called $n a^{\prime} k^{\prime} i n$ : $n a^{\prime}$ is "lady" or "mother" and ' $k^{\prime}$ in is "sun". We should remember that the howler monkey is possibly the most noisy and scandalously obvious of nocturnal animals, and it would be difficult to find a clearer or more appropriate animal prototype as a symbol of the moon than the howler monkey in a tree top, singing to the moon with the loudest of animal voices.

In the calendars of various groups of the Maya area, we find the day name corresponding to the Mexican Ozomatli, "Monkey", divided irregularly between the cognate forms of Chuen and Baatz. This fact in isolation might suggest that the forms are synonyms rather than differential forms, but Maya cosmology and symbolism is usuallv far more complex than we might wish it to be.

22 I should mention that $K^{\prime}$ ulel is one of the rather poorly-characterized of the Lacandon deities. In the Book of Chan K'in, he is said to be the assistant god who sweeps the house of Hachäkyum. During the incense burner renewal ceremony at Najá, when a whirlwind lifted ashes from the pire where the incense burners were being fired, it was thought to be the presence of $K^{\prime}$ ulel, who would take the ashes to Hachäkyum together with the information that the ceremony was nearly over. The whirlwind association suggests a possible Quetzalcoatl-Ehecatl correlation, as does his resemblance to $A h^{\prime} K^{\prime} a k^{\prime}$ in that he is corageous, but something of a liar. The Temple of the Incriptions in Palenque is considered to be his home, and the burial which Dr. Alberto Ruz Lhuillier discovered there in 1954 is said to be K'ulel's Xiw. ("Proxy" or "Android") ... rather than the "Astronaut" that it has become so stylish to see in the graphic representation in low relief on the top of the sarcophagus. (Until I visited Palenque together with Old Chan K'in of Najá, I had been confused by the description of "the highest house" of Palenque belonging to T'uup, the Owner of the Sun. It was finally made clear that the Temple of the Inscriptions, together with its burial, belongs to K'ulel; while the house of $T^{\prime} u$ up, the favorite son of Hachäkyum, is the tower which rises out of the Pallade. The Pallace itself is, of course, the house of Hachäkyum). 
In the solar symbolism (one could also say, "solar and lunar symbolism") of the monkeys, we find a good illustration of the simultaneous multiple levels of symbolism fused, into what would appear to Occidental logic to be a single complex and contradictory level. On the one hand, the sun and moon are symbolized by two monkeys, the spider and howler monkey, respectively. These are personified in the Popol Vuh as Hun Chouen and Hun Batz, and in the Book of Chan K'in a bit less clearly as the Chäk Xib, "Red Lords". They are two brothers. But on the other hand, the sun and moon are husband and wife, so the male spider monkey is called $K^{\prime}$ ulel, the name of a solar deity, but his wife is Cheh, a name derived from Chel or Ix Chel, the "Pale Lady" or the moon. Then as a dualistic mirror image of this symbolism, on the level where it is compounded by the howler monkey representing the moon, his wife is $N a^{\prime} \mathrm{K}^{\prime}$ in, which in this case would apparently be most appropriately left in the English transliteration "Lady Sun". If this is not one of the best illustrations of the traditional Maya manner of shuffling and interlaying distinct levels of symbolism into a single, complex whole; at least it possibly represents one of the best examples which is accessible to a reasonably clear analysis by Occidental logic.

To what degree the classic Mayas distinguished and appreciated each level of symbolism individually, in opposition to their appreciating the whole "layer cake" as a single entity (or more likely, both)... we can only speculate. We are clearly told, however, in the Libro de Chilam Balam de Chumayel, that the ability to shuffle and fuse the multiple levels of symbolism into a single literary construction was called "The Language of Zuyua". An examination in this style of multiple level punning by the $\mathrm{K}^{\prime}$ 'aat $\mathrm{Na}$ 'at, "(He who) Requests Understanding", has been equated to a "Civil Service Examination" and a prerequisite to public office. If this description sounds rather childish and superfluous, we should remember that this literary style presupposed an extreme familiarity with the existing expressions of cosmology, philosophy, literature and oratory of the culture. It was the distinguishing characteristic of the Maya Aristocrat... or "Theocrat", as we may choose to call him.

In summary: In our example of the sun and the moon, we can recognize three distinct, simultaneous levels of symbolism. Looking at them one by one, they are:

1. The Sun and the Moon are two brothers.

2. The Sun and the Moon are brother and sister.

3. The Sun and the Moon are man and wife. 
The first and third characterization are clearly articulated in the Popol Vuh, though for an example of the second, we must look to other mayanse ethnic groups.

1. Hun Hunahpú and Vucub Hunahpú are clearly identified as the two brothers who became (or received) the sun and the moon (Part II, Chapt. 14) even though throughout the rest of the Quiché narrative, they are clearly the same Hunahpú and Xbalanqué, who are the Sun and the Morning Star.

2. The "brothers-sister association" is not expressed in the Popol Vuh, though it is clearly expressed in the Book of Chan K'in in the genealogy of T'uup and Ixchel... though when T'uup thwarts his elder brothers' attempts to kill him, causing them to lose their celestial rank and the favor of their Father, the Lord of Heaven, he is none other than Hunahpú, who, with the help of his brother Xbalanqué, makes monkeys of his despotic elder brothers Hun Batz and Hun Chouen.

3. Hun Hunahpu and $X q u i c$ are the Sun and Moon as man and wife, as are the Lacandon Nuxi' and the "Daughter of Kisin". Moreover, this union of the sun and moon may be recognized in practically every solar deity, whose wife is invariably associable with the moon in one or another aspect: X Piyacoc and Xmucané, Huracán and Xganel or Xcanil (the Lacandon Hachäkyum and Xk'anle'ox), Tepeu and Xtoh (the Lacandon Sukunkyum and Äxnuk), etc.

It becomes clearer and that, no matter how imperatively our Occidental logic may demand a clear-cut, unilinear and unambiguous identification of entities and processes, we are simply not going to find this Aristotelean logic in Maya cosmology unless we proyect it there... and we must admit that such a proyection is an even more serious violation of Occidental scientific procedure (i.e., a specialization of Occidental language and logic) than bypassing facets of other cultures and cosmologies which apparently contradict our basic premises of "proper" thought and conceptualization.

I am reminded of an old and rather idiotic joke about a tourist shop which announced that it had the skull of Jesse James on exhibit. When a passing physical anthropologist asked the owner of the shop "How can this be the skull of Jesse James, when it is the skull of a 14-year-old boy", the owner, undismayed, replied glibly "Precisely, sir. This is the skull of Jesse James when he was a boy." As absurd as this may be, it might be considered to bear a certain 
resemblance to the process of the diversity of deities which (to Occidental thought) are or were originally identical in Maya cosmology. To the Maya's credit however, it should be noted that the distinction between the physical and metaphysical aspects of reality simply does not correspond directly to its counterpart in Occidental thought: In some cases the Maya distinction is more precise, and in others it is more ambiguous. These differences seem blatantly obvious when they violate our logical principles (as in the case cited); but when they improve on them, more often than not, we simply are unable to grasp the significance of the "fine distinctions" involved.

The cyclical or repetitive format of the Popol Vuh.

In order to properly understand, appreciate and analyze the events of the Popol Vuh, it is necessary to recognize the cyclical and repetitive nature of "time" - or more correctly, of reality - in the Solar Cycle, which is the base and foundation upon which all Maya cosmology is built:

Unlike our Occidental "folk concept", according to which the day begins with the rising of the sun, and unlike our astronomical and chronological practice, by which the day begins at midnight (when from 23:59 hours, the clock passes to 0:00 hours of the next day) Maya thought concieves of the beginning at $k^{\prime} a k^{\prime}$ chun$k^{\prime}$ 'in, with the sun at zenith. The Sun warms the earth, gives life to the growing plants, and with His clear light, dispells doubts and ignorance, showing the proper location, relation and distance between all things, and the true proportions of each. The Giver of Life presides over the earth and all is well with the world. But then, even when $\mathrm{He}$ is highest in the heavens, the Sun heeds a call from the Underworld and begins to descend to meet his Destiny.

The Sun - and the Morning Star, until then invisible - sink below the western horizon into the Realm of Darkness, Death and the Shadows. The shadows come forth to take the earth; tiny beings cast great and fearful shadows, and the distinction between the great and the small, the good and the bad, is lost as the Darkness swallows all. The jaguar stalks the jungle trails, and the nocturnal hunters stalk and devour the creatures of the Sun. The cold, the phantoms and a host of known and unknown fears wait for men just beyond the light of their fires.

The Sun himself is captured by the Lords of Xibalba, the Realm of Death. But at the darkest hour, when the death of the Sun would appear to be the most certain and complete, the Morning Star 
rises, marking the way for the Sun's ascent. The eastern horizon takes on the color of blood, then fire, and then the Sun rises. Darkness is anihilated and the shadows flee into the earth, into the caverns and under the rocks and trees. The sun warms the earth, the cold and the mists of the night vanish. The fears and the phantoms vanish, too, as the clear light of day shows the true relation and distance between all things.

This solar cycle is the basic format or pattern to which all Maya Cosmology is subjected. It is the basic manner in which Maya thought concieves of reality. We might compare it with the single cell of an organism, supplied with a complete set of chromasomes capable of determining all the inherent characteristics of the fully developed organism. So the Maya unit or prototype of reality (which to us would be "time") is the single day or "sun" - both called $k^{\prime}$ in. ( $K^{\prime}$ in is also the term for "prophecy" and Äh K' in is "Priest", or more literally, "Prophet". The function in question might he defined as "illuminating that portion of the sequence of the Cycle of Reality which is not yet manifest".)

Just as this cycle is seen in the day, the basic unit of cosmology, it is seen in a greater cycle of the year, called.in Peninsular Maya $y a^{\prime} a x$-k'in, "great-sun" or "great-day". (Ya'ax, besides its basic meaning as a designation of the "shades of color" included in our "greens and blues", has the allusive meaning of "great" or "giant".) In this cycle, or more correctly, in this manifestation of The Cycle, the protagonist is the Corn: The plants grow from tender, green youth to maturity, and are then called to descend to their Destiny in the shadows. The plants wither, they are "decapitated" or harvested, shelled, cooked, ground and eaten... though a few grains are saved. Fire (deified as $A^{\prime} h K^{\prime} a k$, Venus, the Morning Star) clears the earth of the milpa into which the seeds are cast and buried. Then the green shoots ascend, grow to maturity, and the Cycle continues its endless course.

The cycle of the Day - the cosmic prototype- runs many times in the cycle of the corn or the milpa, so important to Maya life; and the milpa cycle runs many times in the lifetime of a man, which is seen as a conformity to the same pattern; and a single cycle of creation contains many human life cycles.

The Popol Vuh becomes properly analyzable only when seen according to this Solar Cycle, repeated one time after another. It is clearly not a single narrative as Occidental thought and logic would tend to see it. 
The Cosmic Cycle(s)

Hunahpú (the Sun) and Xbalanqué (the Morning Star - though on another, simultaneous level of meaning, he would appear to be the moon, especially in this cosmic cycle in which the Lord of Death is identified by the numeral 7 , associable with Venus) begin to establish the order in the world in which the present creation of Man is to live. They combat the Lord of Death and Darkness, who is called in this manifestation of the Cycle, Vacub Caquix, "Seven Macaw".

The Lord of Death captures a part of the body of the Sun, his arm. The Morning Star (Xbalanqué) helps the Sun (Hunahpú) to escape, and together they seek the help of the Creators. They recover the arm of Hunahpú, conquer the Lord of Death and Darkness, and when the Sun is whole again, the Cycle continues. The sons of Vucub Caquix, who are called Cabracán and Zipacná, and who are identified as those who cause earthquakes, may be identified with U Yix Mehen Kisin ("The Begotten Sons of the Causer-of-death"! among the Lacandones. In the Book of Chan K'in, however, it is Kisin, "He who causes Death", who is the Lord of Death, the Earthquake, and he may also be associated with the "Devil", in that he is the antithesis of the life-giving Sun and in that he punishes the souls of the wicked in Metlan after Death.

\section{The Pre-human Cycle(s)}

In Part II of the Popol Vuh, we find Hanahpú and Xbalanqué going about their work of putting the world in order, when they are called by the Lords of Xibalba and begin their descent to the Underworld. They are apparently defeated by the Lords of Death, now called Hun Camé, "One (or Universal) Death", Vucub Camé, "Seven Death", and the other Lords who are called by the names of a host of illnesses, misfortunes and evils. In depths of Xibalba, when the triumph of the Lords of Darkness appears to be complete and certain, they decapitate the Sun and hang his head on the calabash tree. The head of the Sun, however, impregnates the Maiden Xquic (the Moon, Lady of Childbirth, and in the Book of Chan K'in, "the Daughter of Kisin") with its saliva and she returns to Earth to bear his children, who are in fact the same Hunahpu and $X$ balanqué, the Sun and Venus. With their return to earth, the cycle begins anew.

The Sun and the Morning Star again are called to Xibalba, chal- 
lenged to a ball game with the Lords of Death. Each night they stay in Xibalba, they are sent to sleep in one or another "House of Torment", which represent the dangers which the race of Men who are yet to be created must face in life.

They must first cross a "River of Blood", just as the Maya men must face the dangers of discolored flood waters on earth. They sleep in the "House of Cold" in which they would have frozen to death had they not made fire, just as men must protect themselves from the cold. They must sleep in the "House of Knives", in which obsidian knives move and grind against one another, just as the Maya traveler must bear the sharp stones and thorns on the jungle and mountain trails. They sleep in the "House of Jaguars" and survive by assigning to these predators the right to the flesh and bones of animals, but not of men... though men must also cope with the danger of encountering the jaguar on their road through life. Though they pass all these and other trials, the Lords of Xibalba succeed in sending bats to decapitate the Sun, and they hang his head in triumph in the ball court. The Morning Star, however, evokes the gods, fashions a temperary head for Hunahpú, and then (as god of war) takes command of the field and eventually conquers the Lords of Darkness, sacrificing most of them, "limiting their power and lowering their rank." The dominion of Death and Darkeness is no longer absolute, and Man can now live on earth. Hunahpú and Xbalanque restored the Sun and Moon, no longer as abstract, cosmic beings, but as the father and the mother of mankind.

Thus the gods, the Sun and the Morning Star, lived out the cycle in all the general characteristics of the life of Man. A man's life is a repetition of the same cycle as a day, or the life of the Sun. Man, like the Sun, is called to descend to the realm of Death, and he cannot escape this Destiny. He must die just as the Sun dies, but he may continue to live out the cycle again and again in his descendants... just as Our Mother, the moon (then the Maiden Xquic) returned Hunahpú and Xbalanqué from Xibalba to the earth.

Corresponding to these different cycles —or more correctly, to these different manifestations of The Cycle - we may recognize an apparent progression and sequence in the types of order in the Universe:

1. The Creator Gods, cosmic beings, prepare the basis for order in the Universe, according to the format of the solar cycle.

2. The closer and more personal gods (principally the Sun, the Moon and the Morning Star) establish the order which is to 
prevail in the world in which Man must live. More correctly, they simply recognize and conform to this order - which in Maya cosmology is prior to and more elemental than any of the gods- making it manifest.

3. The sacred images are supposedly material representatives of the same true gods, who still speak to men through them, but at a greater distance, and less personally. There appears to be a certain resentment or shadow of mistrust for Tohil, who takes on an importance far out of proportion to his position in the hierarchy. Upon analysis, Tohil is identical with Xbalanqué, the Morning Star and the god of war -also Quetzalcoatlbut Tohil is still another manifestation of this person. At the equivalent stage in fixed Lacandon ritual, the effigy incense burnes of Itsanal and Säkapuk (identifiable with Hunahpú and Xbalanqué, respectively) become of greater importance. In the Popol Vuh, however, at this stage of the sequence, Tohil shares his supreme authority with no one; which suggests that the Quiché may have seen the theocratic military dictator (representing Xbalanqué) taking command in time of crisis - but then refusing to relinquish and return this power to the civil government (representing Hunahpú) again when the crisis has passed -as an integral and inevitable part of the Natural Order.

4. The authority of the Priests and Sacrificers finally constitutes the formal religion of a civilized people. The common man cannot or should not have any contact with the supernatural... except through the authorized intermediaries.

Another immediate problem with far-reaching implications which we find in the identification of deities is the repetitive or multiple character of most of these, and especially of the solar deities. Just as each day, or "sun" is a separate, individual entity - but at the same time, it is the same Sun (also K' in in Peninsular Maya, and Quih in Quiché), with all the same characteristics; so may all the solar deities be derived from the original concept of the Sun as a divinity, though each is a distinct individual.

For example, Xpiyacoc or Hunahpú Vuch of the Popol Vuh corresponds to the Lacandon Remote God $K a^{\prime} k^{\prime} o c h$ or K'akoch, who is the "Ancient Sun", an arbitrary and dangerous thing, which would be extinguished "at the end of every year", and which would not shine again until massive human sacrifices were conducted.

Tepeu of the Popol Vuh corresponds to the Lacandon Sukunkyum, 
"Elder-Brother-of-Our-Lord", who is the "Dead Sun" or "Lord (Sun) of the Dead". ${ }^{23}$

Gugumats of the Popol Vuh is the Lacandon Akyantho'. This is possibly the most complex and confusing of the "Maya Trinity", as on the one hand, he is the "Second Sun" and creator of foreigners (and enemy or invading warriors) and thus associable with the Yucatec Kukulcán (literally the same name as Gug-cumatz) and the Toltec Quetzalcoatl; but on the other hand, all these manifestations of a single Mesoamerican deity are the Morning Star (Venus) rather than the Sun. But here again comes added complexity, as Tohil of the Popol Vuh - who is quite clearly the Lacandon $\ddot{A} h K^{\prime} a k^{\prime}$ (and in Yucatán, Ah Kak appears to be one of the titles of the two $\mathrm{Na}$ con or Nacom) -is clearly identifiable as the Morning Star. At the same time, however, Xbalanqué, corresponding to the Lacandon $N u x i^{\prime}$ or $N u x i^{\prime} K^{\prime} a k^{\prime}$, is just as clearly identifiable as the Morning Star... and to add to the appearance of confusion, the Lacandon Nuxi' appears to be a fusion of both Hunahpú and Xbalanqué. The Yucatec Ek Chuah is equally associable with Gugumats, Xbalanqué and Tohil in the Popol Vuh. ${ }^{24}$

There would appear to be no limit to which different aspects or manifestations of a single original deity may evolve into independent deities. Nor can we be certain to what degree the simultaneous unity and diversity of the deities in question is in agreement or disagreement with Maya logic. Our Occidental logic runs aground at our relatively simple Dogma of the Trinity (i.e., the simultaneous unity and diversity of Father, Son and Holy Ghost), and logic must, in fact, be discarded and replaced with "Faith". In view of the fact that the Mayas went to even greater extremes in this line, I am afraid that our traditional logic will require much patient grinding away, and widening of criteria, before we can do anything with these even more complex and confusing cases. I can only say that it is a pity that one of the early Spanish missionaries didn't let one of the Maya priests explain the concept of the Trinity to him, for the benefit of Christian philosophers.

${ }^{23}$ This same deity has the titles Itsanachaak and Kk Cham Yum Klin, subject to multiple simultaneous translations, abich invariably leave one with a certain dissatisfying feeling of incompletion and doubt when considering any one of these meanings in isolation. Cf. El Libro de Chan K'in, pp. 3612, 364 .

24 The material presented by the Brasilian investigator Antonio Porro (op cit.) could be interpreted as a good argument for the identification of the Lacandon Nuxi' $K^{\prime} a k^{\prime}$ as the Mexican Quetzalcoatl. 
Huracán or U Qux Cah, "The Heart of Heaven" of the Popol Vuh is the Lacandon Hachäkyum (or Hach Äk Yum, "Truly Our Lord"), also called Yumbili Ka'an, "Lord of Heaven" or "Lord Heart of Heaven", and among the Southern Lacandones, U Yol-i $(l)$ $K a^{\prime} a n$, literally, "The Heart of Heaven"; and throughout most of the Peninsular Maya area, Äk Yum, "Our Lord", a term with about the same semantic content and distribution as Hunahpú in the Popol Vuh. This is the Principal Solar Deity, and may be considered "The Present Sun", though this clear identification appears to have been far too simple and vulgar for Maya cosmological thought.

Among the sons of the principal solar deity, we find that Hun Chouen and Hun Baatz, the elder brothers of Hunahpú and Xbalanqué, were turned into monky because they were cruel and despotic with their younger brothers. These correspond to the Chäk $X i b$, "Red Lords", the two firstborn sons of Hachäkyum, who lost their right to "ascend to heaven" when they attempted to murder their younger brother, T'uup, the "Owner of the Sun". These same persons appear to be those referred (or alluded) to in Yucatán as Maax Kin, "(Spider) Monkey Sun" and in the Highland Maya surname Chel-baatz, "Pale (or Lunar)-Howler Monkey".

The progression of the heirarchy of the solar deities continues in descending order of status and/or importance, until we find the recognition of the sun as an astronomical phenomenon in the poor, imperfectly resurrected Hun-Hunahpú and/or Vucub Hunahpú (Part II, Chapt. 14): "They found his body, but it could do very little. It could not pronounce his name, this Hunahpú-il. Neither could his mouth say it." And in the Book of Chan K'in (Chapt. XXV) the sun is described as a poor being, barely alive, which Sukunkyum carries, feeds and cares for each night in the Underworld.

From the point of view of Maya Cosmology, as it appears in the comparison of the Popol Vuh with Book of Chan K'in and other selected bits of folklore from the Maya Area, it seems rather clear that Maya Cosmology - which was a continuation of that of the Olmec culture- had its remote origin in the worship of the Sun as the Giver of Life and Supreme Deity. (The Sun was married to the Moon and accompanied by the Morning Star.) But in the course of this cosmology's long evolution, all the different aspects and manifestation of this original Supreme God became personified in an equally great number of individual gods. This would be something of a reversal of the supposedly universal tendency of evolution from polytheism to monotheism, in that something very close to an original 
solar monotheism developed into the refined and complex polytheism which was Maya religion.

\section{A BASIC PATTERN FOR THE ANALYSIS OF THE MESOAMERICAN PANTHEON}

By way of conclusión to this monograph - which began as an answer to the challenge to the anthenticity of the Popol Vuh -I should like to point out that the comparison of the Popol Vuh with each and every bit of new data from related mayanse traditions and ethnic groups, yields greater understanding of Maya culture in general. (Probably this fact alone is quite enough to say about the authenticity of the Popol Vuh.) With each extension of our knowledge of Maya and mayanse cultures, it is possible to establish new parallels and conclusions regarding basic Mesoamerican culture, thought and symbolism.

In the process of preparing a correlation of Quiché and Lacandon deities, I devised a diagram which would appear to represent the basic structure and symbolism of Mesoamerican cosmology in general. Obviously there are individual variations between one ethnic group and another, and there is no perfect correlation between Quiché and Lacandon gods... but the basic outline of the symbolic sub-structure of the cosmology is quite valid, not only for the comparison of Lacandon and classic Quiché, but for Yucatec and ancient Mexican also.

In some points it is rather clear that a single deity may be recognized throughout Mesoamerica, with a different name in each culture, but with essentially the same characteristics. For example: The Remote Creator Couple, corresponding to the Lacandon $\mathrm{Ka}^{\prime}$ $k$ 'och, whose, wife's name and function have been lost; among the Quiché were Xpiyacoc and Xmucané; among the ancient Mexicans, they were Ome-Tecuhtli and Ome-Cihuatl, respectively. In ancient Yucatán, it is not clear exactly what they were called, though in the codices, they are represented by the "older" or more ancient representations of the principal solar deities.

The rain god, so important throughout Mesoamerica, is clearly identifiable as the Lacandon Mensäbäk, the Yucatec Yum Chaac, and the Mexican's Tlaloc; but in the Popol Vuh, he is not mentioned at all, as one of the most striking characteristics of the Maya Highland cultures (including the ancient Quiché, as well as the present day Mam, Tzeltal-Tzotzil, Tojolabal, etc.) is the absence of the 
rain god as an independent person in the pantheon. This is simply a function of the principal solar deity.

The principal solar deity, the Quiché Huracán or "Heart of Heaven" is the Lacandon Hachäkyum, and the Yucatec Itzamná; but the exact character of Huitzilopochtli ${ }^{25}$ is rather weak and poorly defined, due to the dominance of Quetzalcoatl, the Morning Star as god of war, and his extreme importance in the militant and empirialistic culture of Anahuac.

Thus by extending this basic pattern to the analysis of other expressions of Mesoamerican cosmology, such as the Mixtec and Zapotec cultures, for example, not only would the pattern help in the identification and analysis of the characteristics of the gods in any given culture of this area, but each culture studies (once its individual variants are recognized and evaluated) would contribute to the more precise definition of the Mesoamerican prototype deities.

I should also point out that the present outline, presented here as a working hypothesis (to be elaborated and modified as necessary), includes only: Sun, Moon and Venus lines, with Rain and Lightning lines (eavily influenced by Solar and Venus characteristics, respectively) for Peninsular Maya and Mexican areas, as opposed to Highland Maya (and possibly other) areas of Mesoamerica. The underworld deities here listed would appear to be the "nocturnal proyections" of the same lines of deities associable with the mentioned cosmic phenomena.

Missing are what would appear to be the earth deities, such as the Lacandon and Yucatec Känänk'ax (written Canankax -with approximately the same phonetic value- in Yucatán), a class of deities who can be identified as Mexican Tepeyolotl.

I should also point out that I have limited myself to placing the deities in question on the corresponding "line" (i.e., solar, Venus, etc.), and have not been too concerned about the obvious cases of duplication, overlapping and imprecision in the identification and correlation of one and another deity between the different cultures. For example, on the one hand, the Lacandon T'uup is Hunahpu when he is victorious over his abusive older brothers (the Chäk Xib, "Red Lords", corresponding to Hun Batz and Hun Chouen), but in the greater part of the correlations of identical incidents between the two narratives, it is Nuxi' who is recognizable as Hunahpu. This

${ }^{25}$ It would appear to me that the identification of Huitzilopochtli as $\mathrm{Hu}$ nahpú, and of Quetzalcoatl as Xbalanqué (through their Mesoamerican prototypes) is but a step farther in the direction undertaken by Antonio Porro (op. cit.). 
throws into relief the artificial distinction between "Hun Hunahpu and Vucub Hunahpu" on the one hand with Hunahpu and Xbalanqué on the other: The Hun and Vucub (1 \& $7=$ Sun \& Venus) simply indicate another manifestation of the same persons, and the term "their fathers" couldn't be taken literally anyway (according to Occidental logic) except as an error, as Hunahpú and Xbalanqué were the sons of the head of Hun Hunahpú, while Vucub Hunahpú $(=X$ balanqué $=$ Venus $)$ died without progeny. Still the Quiché author of the Popol Vuh speaks of "their fatherS", to refer to the same personifications of the Sun and the Morning Star in the previous cycle. Then, too, the Popol Vuh shows clearly by comparison the loss of elements in contemporary Lacandon culture. The term $N u x i$ ' $K$ ' $a k$ ' in Lacandon tradition clearly should refer to ' $N u x i$ ' and $K^{\prime} a k^{\prime}$ ', or to Hunahpú and Xbalanqué, respectively. Once again, however, in the case of the Lacandon Fire Lord, $\ddot{A} h K^{\prime} a k^{\prime}$, he may be clearly recognized in some cases as Xbalanqué, though usually he is clearly identifiable as Tohil in the Popol Vuh.

The imprecision and contradictory character of the "Second Sun", who is so clearly the Morning Star on the cosmic (or remote cosmic) level of symbolism - the Lacandon Äkyantho', the Quiché Gugcumatz, the Yucatec Kukul-cán, the Mexican Quetzal-coatl- remain as possibly the greatest dissatisfaction to our Occidental logic. While on the one hand, one can say that "The Morning Star is the Sun before the real Sun rises"... and this can be observed as an integral and natural part of the Solar Cycle (and even associated with the original symbolism of our "Lucifer, Son of the Morning") ... on the other hand, in all other cases, the differentiation of Venus and Solar characteristics is one of the prime elements of Maya cosmology. Only in the "nocturnal projections" of these same lines does a similar confusion occur: On the one hand, the Lacandon Sukunkyum is the "nocturnal projection" of the Sun, while Kisin is apparently the negative counterpart of $A^{\prime} h K^{\prime} a k$ ' the Morning Star and originally the god of war at the service of the principal solar deity. (In the Mexican codices one can also recognize an apparently benevolent Lord of the Underworld in opposition to the more malignant Lord of Death - either Teoyaomiqui vs. Mictlantecuhtli, or possibly either of these vs. the grotesque Tlaltecuhtii). On the other hand, though, while the Lords of Xibalba Hun Camé and Vucub Camé would appear to be identified by the numerals $1 \& 7$ as the "nocturnal projections" of the Sun and Venus, respectively (i.e., the exact counterparts of Hunahpú and Xbalanqué) ... but Hun Camé is charac- 
terized by no solar benevolence (i.e., as could be expected of Sukunkyum/Tepeu), but is every bit as clearly Xbalanque's evil, made-inXibalba Dopelganger as is Vucub Caquix.

With this multiplicity of deities, all rather comfortably identified as "Morning Star" or as "Sun"... or their respective "nocturnal proyections", I can clearly hear Sir Eric's classic epitath for anyone who is vague or ambivalant with his handling of ideas, or who comes anywhere near contradicting himself: "That's playing poker with the duces wild!" I, too, enjoy a good, formal game (i.e., with only the joker wild for aces, straigths and flushes) ... but what is important is not our idea of what is good sport, but how the Mayas played the game. All my studies point toward the unhappy conclusion that the Mayas used an exasperating (for us) number of "wild cards".

If this would offend our Occidental logic in philosophy, perhaps we should take another look at this same characteristic ambiguity or imprecision as it appeared as an element of the traditional Maya literary style: In the latter part of Chapt. 9, Part II of the Popol Vuh, when the Lords of Xibalba demanded that Hunahpu and Xbalamqué cut four different kinds of flowers for them during the night "A branch of red chipilin, a branch of white chipilin, a branch of yellow chipilin, and a branch of carinimac", - this sounds rather silly, trivial and meaningless... until we consider that the colors red, white and yellow in Maya cosmology represent the east, north and south, respectively. Carinamac has not been identified, but it was almost certainly considered to be "black" $\left(e k^{\prime} / e q\right)$, the color representing "west". Thus we may be quite certain that what this is all about is that the Lords of Xibalba were sending Hunahpu and Xbalanqué to the four corners of the earth in a single night (the same night, no doubt, that they slept in the "House of Knives"). It would appear that the Mayas would tolerate almost any degree of logical contradiction or apparent triviality, provided the real meaning(s) were allowed to get through to the perceptive, cultivated, sensitive, "real person" with proper grace and style. If we succeed only in seeing the logical contradictions and triviality, then we are missing the "real message(s)", and are not yet well-educated enough, by Maya standards, to know what the literary or artistic expression was all about.

Let us continue our studies of Maya culture a while longer before we consider that we really understand a iterary expression such as the Popol Vuh or the Book of Chan K'in. 


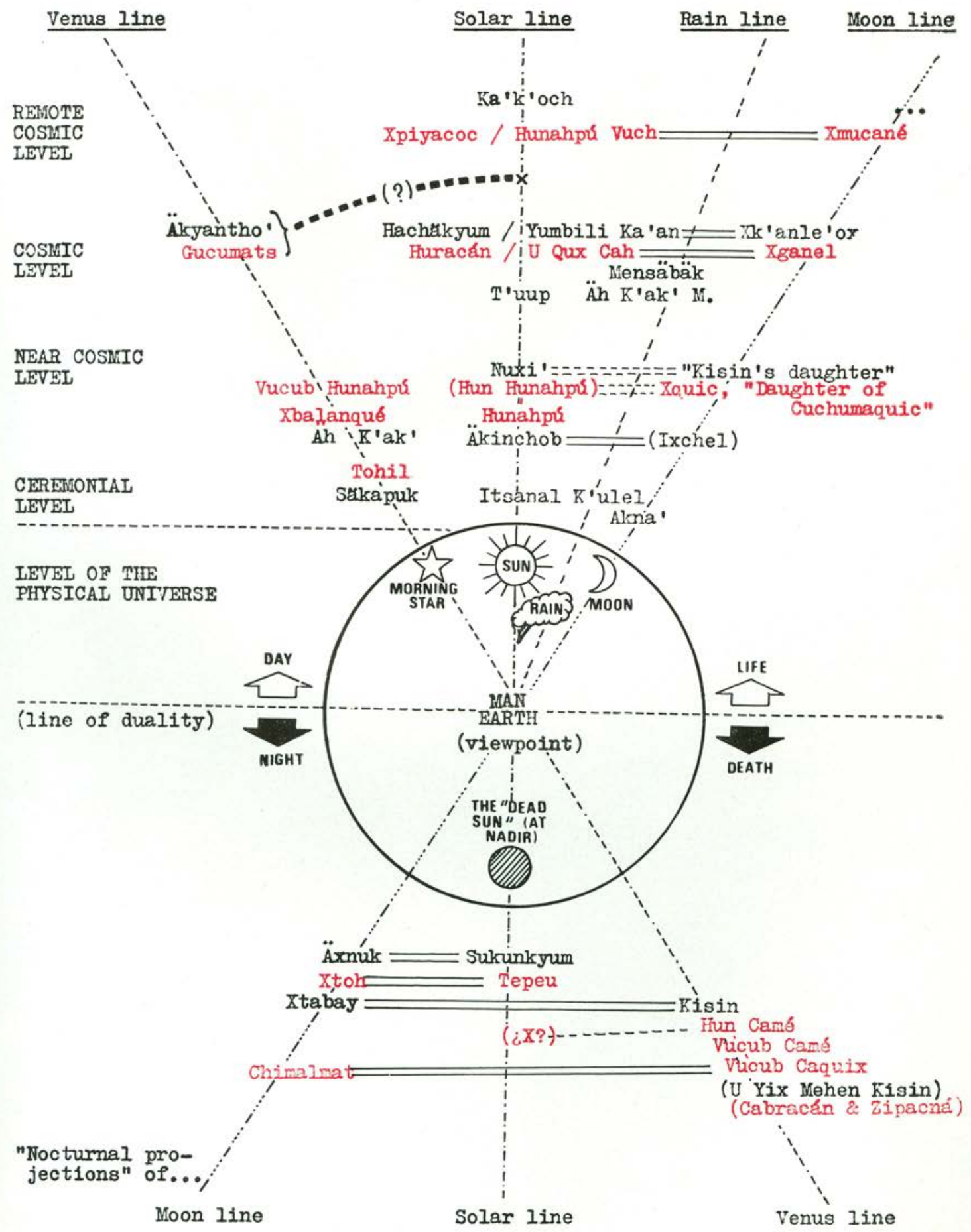

Mapa de la Cosmología Maya 